\title{
Combustion synthesis of Co-Cu-Mn oxides deploying different fuels
}

María Celeste Gardey Merino ${ }^{1}$, RominaArreche ${ }^{2}$, María Silvina Lassa ${ }^{3}$, Gustavo Enrique Lascalea ${ }^{4}$, Alfredo Estrella ${ }^{1}$, Mariana Estela Rodriguez ${ }^{1}$

\footnotetext{
${ }^{1}$ CLIOPE Group, National Technological University - Regional Faculty Mendoza, Rodríguez 273, Mendoza (M5502AJE), Argentina.

e-mail: mcgardey@,frm.utn.edu.ar

${ }^{2}$ Research and Development Center of Applied Science "Dr. Jorge J. Ronco" (CINDECA) CCT CONICET - La Plata, National University of La Plata, 47 street No. 257, La Plata (B1900AJK), Buenos Aires, Argentina.

${ }^{3}$ Electron Microscopy and Microanalysis Laboratory (MEByM)-IANIGLA - CONICET - Mendoza, Av. Ruiz Leal s/n Parque Gral. San Martín, Mendoza (M5501IRA), Argentina.

${ }^{4}$ Environmental Chemistry Laboratory (LQA) -IANIGLA - CONICET - Mendoza, Av. Ruiz Leal s/n Parque Gral.San Martín, Mendoza (M5501IRA), Argentina.

e-mail others authors: arrecheromina@gmail.com, silvina.lassa@gmail.com, glascalea@mendoza-conicet.gob.ar, alfredoestrella_37@hotmail.com; mariana_ro24@hotmail.com.
}

\begin{abstract}
Ternary spinel-like oxides such as $\mathrm{CuFeMnO}_{4}, \mathrm{CoCuMnO}_{\mathrm{x}}$ and $\mathrm{CuCr}_{2} \mathrm{O}_{4}$ are attractive materials due to their absorbent properties when used as pigments for selective surfaces thus improving solar heaters efficiency. These materials are obtained through sol-gel and sol-gel-combustion methods. This work proposes the synthesis of mixed oxides of $\mathrm{Co}, \mathrm{Cu}$ and $\mathrm{Mn}$ by means of original one-step stoichiometric combustion methods starting from $\mathrm{Mn}\left(\mathrm{NO}_{3}\right)_{2}, \mathrm{Co}\left(\mathrm{NO}_{3}\right)_{2} 6 \mathrm{H}_{2} \mathrm{O}, \mathrm{Cu}\left(\mathrm{NO}_{3}\right)_{2} 3 \mathrm{H}_{2} \mathrm{O}$ and Aspartic acid (Asp) or Lysine( Lys) as fuels. The resulting ashes after the combustion were calcined at $500{ }^{\circ} \mathrm{C}$. The obtained ashes and the calcined powders were characterized by X-ray diffraction (XRD), scanning electron microscopy (SEM), transmission electron microscopy (TEM), Fourier transform infrared spectroscopy (FTIR), and by Brunauer-EmmettTeller method (BET), and TG-DTA analysis. In calcined powders obtained with Lys (CoCuMnO $-\mathrm{Lys})$, the phase corresponding to $\mathrm{CoCuMnO}_{\mathrm{x}}$ and others segregated phases were identified. However, in calcined powders obtained with Asp $\left(\mathrm{CoCuMnO}_{\mathrm{x}}\right.$-Asp) only the phase corresponding to $\mathrm{CoCuMnO}_{\mathrm{x}}$ was identified. The sample $\mathrm{CoCuMnO}_{\mathrm{x}}$-Lys presented an average crystallite size of $44 \mathrm{~nm}$ and a specific surface area of 23 $\mathrm{m}^{2} / \mathrm{g}$ while in $\mathrm{CoCuMnO}_{\mathrm{x}}-\mathrm{Asp}, 54 \mathrm{~nm}$ and $13 \mathrm{~m}^{2} / \mathrm{g}$ values were obtained throughout FT-IR vibrational modes associated with spinel metallic oxides for both calcined powders (Asp and Lys) were observed. Additionally, by means of TEM, polyhedral particles with an average size of 20 to $100 \mathrm{~nm}$ were observed. In particular, it was determined in $\mathrm{CoCuMnO}_{\mathrm{x}}$-Lys an average size of $44 \mathrm{~nm}$. According to the different fuels used (Asp and Lys), an evident variation in the obtained phases was observed. However, it was not obtained any difference in crystallite size and specific area surface values. It is of considerable importance the study of further syntheses processes to verify this trend.
\end{abstract}

Keywords: Combustion syntheses, spinel-like oxides, selective paints, pigments, nanostructured materials.

\section{INTRODUCTION}

In solar thermal conversions systems like solar heaters, the efficiency strongly depends on the materials used in absorbent coatings, particularly on their optical properties and thermal stability [1]. Ternary spinel-like oxides are very attractive as absorbent materials in photo-thermal conversion because they present a high solar absorption. Oxides like $\mathrm{CuFeMnO}_{4}, \mathrm{CoCuMnO}_{\mathrm{x}} \mathrm{yCuCr}_{2} \mathrm{O}_{4}$ are used in selective surfaces for solar collectors. These surfaces present a high absorption $(\alpha)$ in solar spectrum and a low infrared emittance $(\varepsilon)$. The ratio between $\alpha$ and $\varepsilon: \alpha / \varepsilon$ is called optical selectivity.

The usually chosen methods applied for getting these mixed oxides are sol-gel. In particular, the use 
of dipping techniques is almost a routine to get synthesized thin films and by means of sol-gel-combustion is possible to get powders to be used as absorbent pigments in selective paints. In the last decade, $\mathrm{CuFeMnO}_{4}$ was used like an absorbent pigment. However, the powders presented a red-brown color which decreased their absorption capability due to $\mathrm{Fe}_{2} \mathrm{O}_{3}$ segregation for thermal treatment. So that, it was decided to replace $\mathrm{Fe}$ for Co to obtain $\mathrm{CoCuMnO}_{x}[2]$ by sol-gel methods [3] in which the oxide was frequently contaminated by metal oxides, chlorides and oxi-chlorides [2] . On the other hand, spinel-type pigments like $\mathrm{CuCr}_{2} \mathrm{O}_{4}$ and $\mathrm{CoCuMnO}_{\mathrm{x}}$ to be applied on solar selective surfaces, have been synthesized by sol-gel combustion deploying citric acid as fuel. The results reveal that selective surfaces composed of CoCuMnOx pigments show a better optical selectivity than those based on $\mathrm{CuCr}_{2} \mathrm{O}_{4}[\underline{1}]$.

By combustion synthesis is possible to obtain nanoparticles with a homogenous crystalline structure by a one step and simple route. The parameters that influence on combustion reactions include: type of fuel, fuel to oxidizer ratio, use of excess oxidizer, ignition temperature, and water content of the precursor mixture [7]. The effect of fuel to oxidizer ratio in microstructure were studied in the synthesis of $\mathrm{Co}_{3} \mathrm{O}_{4}$ using urea as fuel [ $\left[\underline{]}\right.$, the influence of glycine and urea as fuels were studied to obtain $\mathrm{Co}_{3} \mathrm{O}_{4}$ by stoichiometric combustion synthesis and in studies for optimized combustion reaction to obtain $\mathrm{Al}_{2} \mathrm{O}_{3}$ with eight different fuels as lysine, glutamine, arginine, among others [9].

This work is aimed to the study of combustion synthesis to obtain absorbent pigments for solar selective paints and to evaluate the influence of fuels used in obtained pigments. The production of $\mathrm{Co}, \mathrm{Cu}, \mathrm{Mn}$ mixed oxides by means of original one-step stoichiometric combustion methods starting from $\mathrm{Mn}\left(\mathrm{NO}_{3}\right)_{2}$, $\mathrm{Co}\left(\mathrm{NO}_{3}\right)_{2} 6 \mathrm{H}_{2} \mathrm{O}, \mathrm{Cu}\left(\mathrm{NO}_{3}\right)_{2} 3 \mathrm{H}_{2} \mathrm{O}$ and Aspartic acid (Asp) or Lysine (Lys) as fuels were performed. The obtained ashes after combustion were exposed to a two-hour-calcination at $500{ }^{\circ} \mathrm{C}$. The ashes and resulting powders were characterized by X-ray diffraction (XRD), scanning electron microscopy (SEM), transmission electron microscopy (TEM), Fourier transform infrared spectroscopy (FTIR), and by Brunauer-EmmettTeller method (BET) and thermal analysis like DTA and TGA.

\section{MATERIALS AND METHODS}

$\mathrm{CoCuMnO}_{\mathrm{x}}$ powders have been obtained by stoichiometric syntheses using two different fuels; Asp whose molecular formula is $\mathrm{C}_{4} \mathrm{H}_{7} \mathrm{NO}_{4}$ and Lys, $\mathrm{C}_{6} \mathrm{H}_{14} \mathrm{~N}_{2} \mathrm{O}_{2}$.

\subsection{Synthesis with aspartic acid}

Firstly, it was dissolved $5 \mathrm{~g}$ of $\mathrm{Co}\left(\mathrm{NO}_{3}\right)_{2} \cdot 6 \mathrm{H}_{2} \mathrm{O}$ (Aldrich) and $1,43 \mathrm{~g}$ de Asp $\left(\mathrm{C}_{4} \mathrm{H}_{7} \mathrm{NO}_{4}\right.$, Aldrich) in distilled water, in a $1 \mathrm{~L}$ precipitation glass, getting a first solution with a $\mathrm{pH}=3$. Then, it was prepared a second solution dissolving $2 \mathrm{~g} \mathrm{de} \mathrm{Cu}\left(\mathrm{NO}_{3}\right)_{2} \cdot 3 \mathrm{H}_{2} \mathrm{O}$ (Aldrich) and $0,8 \mathrm{~g}$ de Asp in distilled water, with a $\mathrm{pH}=2$. A third solution was made dissolving $5 \mathrm{~g}$ of $\mathrm{Mn}\left(\mathrm{NO}_{3}\right)_{2}(10 \mathrm{~mL})$ and 2,48 $\mathrm{g}$ of Asp whose $\mathrm{pH}$ was also equal 2.

Finally, the tree solutions were mixed achieving a base solution not showing precipitation. This solution was concentrated on a hot plate (HP) at $250{ }^{\circ} \mathrm{C}$. When there was little remaining liquid, the combustion ignited with sparks and flame. The resulting ashes were placed one hour at $200{ }^{\circ} \mathrm{C}$ in a furnace to complete the reaction. Then, the black ashes were exposed to a two-hour-calcination at $500{ }^{\circ} \mathrm{C}$ in air resulting in a sample labeled as CoCuMnO-Asp.

The selection of quantities was carried out based on the stoichiometric reactions for the obtention of $\mathrm{Co}_{3} \mathrm{O}_{4}, \mathrm{MnO}$ and $\mathrm{CuO}$ shown in reactions 1,2 and 3 respectively.

$$
\begin{aligned}
& 45 \mathrm{Co}\left(\mathrm{NO}_{3}\right)_{2} 6 \mathrm{H}_{2} \mathrm{O}+28 \mathrm{C}_{4} \mathrm{H}_{7} \mathrm{NO}_{4} \rightarrow 15 \mathrm{Co}_{3} \mathrm{O}_{4}+59 \mathrm{~N}_{2}+112 \mathrm{CO}_{2}+368 \mathrm{H}_{2} \mathrm{O} \\
& 3 \mathrm{Mn}\left(\mathrm{NO}_{3}\right)_{2}+2 \mathrm{C}_{4} \mathrm{H}_{7} \mathrm{NO}_{4} \rightarrow 3 \mathrm{MnO}+4 \mathrm{~N}_{2}+8 \mathrm{CO}_{2}+7 \mathrm{H}_{2} \mathrm{O} \\
& 15 \mathrm{Cu}\left(\mathrm{NO}_{3}\right)_{2} 3 \mathrm{H}_{2} \mathrm{O}+10 \mathrm{C}_{4} \mathrm{H}_{7} \mathrm{NO}_{4} \rightarrow 15 \mathrm{CuO}+20 \mathrm{~N}_{2}+40 \mathrm{CO}_{2}+80 \mathrm{H}_{2} \mathrm{O}
\end{aligned}
$$

\subsection{Synthesis with lysine}

This synthesis was carried out in the same way of the previous one using for the first solution $5 \mathrm{~g}$ of $\mathrm{Co}\left(\mathrm{NO}_{3}\right)_{2} \cdot 6 \mathrm{H}_{2} \mathrm{O}$ (Aldrich) and $0,85 \mathrm{~g}$ of Lys $\left(\mathrm{C}_{6} \mathrm{H}_{14} \mathrm{~N}_{2} \mathrm{O}_{2}\right.$, Aldrich) dissolved in distilled water with a $\mathrm{pH}=5$; for the second one, $2 \mathrm{~g}$ of $\mathrm{Cu}\left(\mathrm{NO}_{3}\right)_{2} \cdot 3 \mathrm{H}_{2} \mathrm{O}$ (Aldrich) and $0.5 \mathrm{~g}$ of Lys were dissolved in distilled water, with a $\mathrm{pH}=3$; for the third, $5 \mathrm{~g}$ de $\mathrm{Mn}\left(\mathrm{NO}_{3}\right)_{2}(10 \mathrm{~mL})$ and 1,18 $\mathrm{g}$ of Lys were dissolved in distilled water, with a 
$\mathrm{pH}=2$. Finally, the tree solutions were mixed achieving a base solution not showing precipitation. After HP heating, when there was little remaining liquid, the combustion ignited without sparks and flame. Afterwards, the process followed the same procedure described.

The resulting powders after calcination are labeled CoCuMnO-Lys. The selection of quantities wascarried out based on stoichiometric reaction for the obtention of $\mathrm{Co}_{3} \mathrm{O}_{4}, \mathrm{MnO}$ and $\mathrm{CuO}$ shown in reactions 4, 5 and 6 respectively.

$$
\begin{aligned}
& 51 \mathrm{Co}\left(\mathrm{NO}_{3}\right)_{2} 6 \mathrm{H}_{2} \mathrm{O}+14 \mathrm{C}_{6} \mathrm{H}_{14} \mathrm{~N}_{2} \mathrm{O}_{2} \rightarrow 17 \mathrm{Co}_{3} \mathrm{O}_{4}+65 \mathrm{~N}_{2}+84 \mathrm{CO}_{2}+404 \mathrm{H}_{2} \\
& 17 \mathrm{Mn}\left(\mathrm{NO}_{3}\right)_{2}+5 \mathrm{C}_{6} \mathrm{H}_{14} \mathrm{~N}_{2} \mathrm{O}_{2} \rightarrow 17 \mathrm{MnO}+22 \mathrm{~N}_{2}+30 \mathrm{CO}_{2}+35 \mathrm{H}_{2} \mathrm{O} \\
& 17 \mathrm{Cu}\left(\mathrm{NO}_{3}\right)_{2} 3 \mathrm{H}_{2} \mathrm{O}+5 \mathrm{C}_{6} \mathrm{H}_{14} \mathrm{~N}_{2} \mathrm{O}_{2} \rightarrow 17 \mathrm{CuO}+22 \mathrm{~N}_{2}+30 \mathrm{CO}_{2}+86 \mathrm{H}_{2} \mathrm{O}
\end{aligned}
$$

\subsection{Characterization of materials}

The phases contained in the ashes and powders were identified by XRD using a Philips PW 1710 with a copper anode and a curve graphite monochromator. Additionally, it was determined the average crystallite size from the breadth of Bragg peaks using the Scherrer equation with the peak at $2 \theta=36^{\circ}$. The morphology of the powders was observed through SEM with a Philips 505 microscope. The shape and size of the particles were observed by TEM with a JEOL 100 CX II (JAPAN, 1983) microscope using a voltage of $100 \mathrm{kV}$. FTIR of powders were obtained by a Bruker IFS 66. Textural properties were obtained by BET technique with a MicromeriticsAccusorb 2100. The Thermal analysis DTA and TGA were performed in a thermal balance Shimadzu DTG-60 model with air at $20 \mathrm{~mL} / \mathrm{min}$, with a rate of $10^{\circ} \mathrm{C} / \mathrm{min}$ between 25 and $850{ }^{\circ} \mathrm{C}$.

\section{RESULTS AND DISCUSSION}

Diffraction diagrams for ashes and calcined powders obtained with Lys and Asp are shownin Figs. 1 and 2 respectively.

The phases identified in ashes of CoCuMnO-Lys obtained after combustion were diverse, among them the corresponding to the main peak was $\mathrm{Co}_{3} \mathrm{O}_{4}$, being the rest of the phases specified in Fig 1 . After $500{ }^{\circ} \mathrm{C}$ calcination, the desired phase of $\mathrm{CoCuMnO}_{\mathrm{x}}$ are formed in the sample CoCuMnO-Lys, corresponding to card PDF $\mathrm{N}^{\circ}$ 47-0324 together with other segregated phases like $\mathrm{Mn}_{2} \mathrm{O}_{3}$ and $\mathrm{CuO}$ shown in Fig. 1. The same occurs in sol-gel combustion synthesis of $\mathrm{CoCuMnO}_{x}$ using citric acid as fuel where the desired phase only appears above $500{ }^{\circ} \mathrm{C}$ equally mixed with other phases [2] , and in the powders obtained by sol-gel synthesis apart from the $\mathrm{CoCuMnO}$ phase, it appears segregated other phases like $\mathrm{Mn}_{2} \mathrm{O}_{3}$ after calcined at $500{ }^{\circ} \mathrm{C}$ [4] .

In the case of ashes of the sample CoCuMnO-Asp a similar situation to that described for Lys occurred: It was identified more than one phase as in $\mathrm{Co}_{2} \mathrm{MnO}_{4}$ associated to the main peak being tenorite $(\mathrm{CuO})[4]$ among other phases observed. After calcination, the desired phase of $\mathrm{CoCuMnO}_{\mathrm{x}}$ was identifiedin the CoCuMnO-Asp sample apparently pure, as the peaks shown in Fig. 2 (see above) evidenced.

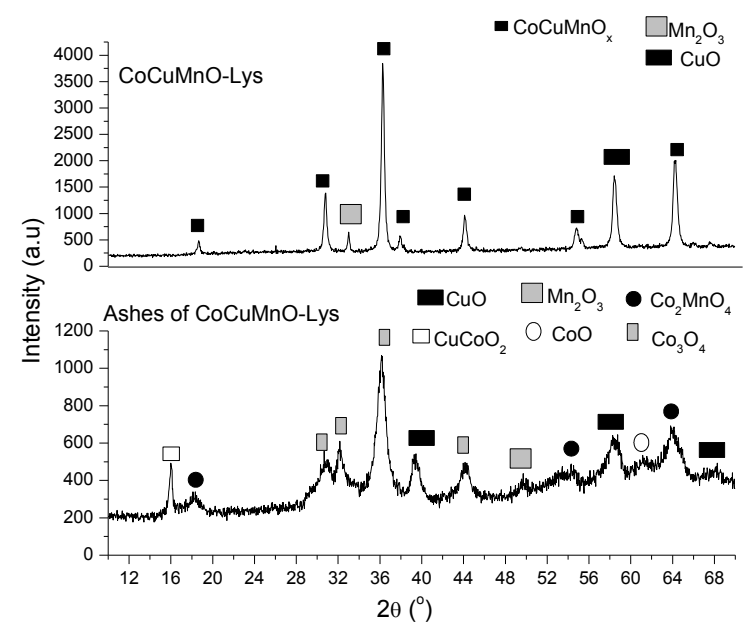

Figure 1: Diffraction diagrams for ashes (down) and calcined powders (up) obtained with Lys. 


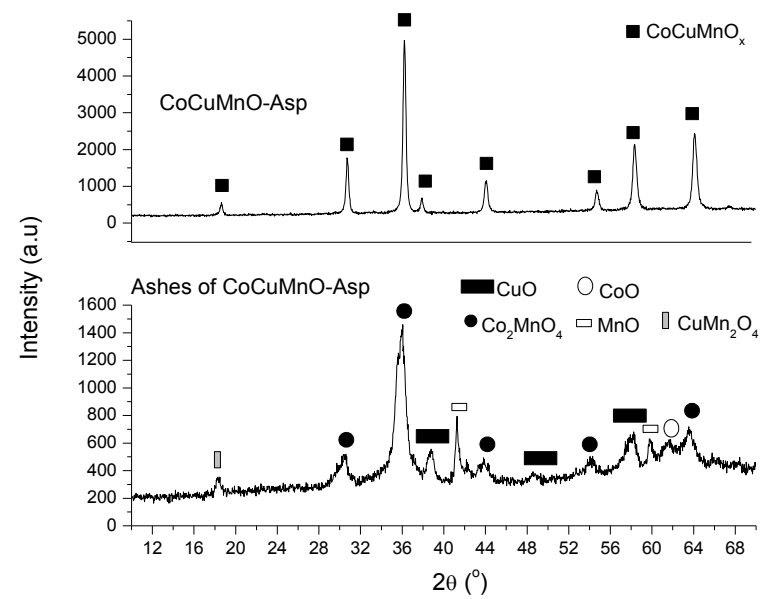

Figure 2: Diffraction diagrams for ashes (down) and calcined powders(up) obtained with Asp.

Regarding the crystallite sizes, the average values obtained for ashes in calcined powders associated with a main peak of around $36^{\circ}$ are listed in Table 1 . The sample CoCuMnO-Asp exhibited a size of $44 \mathrm{~nm}$, smaller than the sample CoCuMnO-Lys, of $54 \mathrm{~nm}$. For powders obtained by sol-gel synthesis, the crystallite was smaller than or equal to $14 \mathrm{~nm}$ [2]. The values of crystallite size for ashes of both samples were smaller compared with the corresponding calcined powders, and under 20nm. On the other hand, the surface specific area (Table 1) determined by BET technique of CoCuMnO-Lys sample was $23 \mathrm{~m}^{2} / \mathrm{g}$ and bigger than the CoCuMnO-Asp sample of $13 \mathrm{~m}^{2} / \mathrm{g}$. The area of the ashes was bigger than the corresponding powders. According to the different fuels used (Asp and Lys), an evident variations in the obtained phases is observed, being these differences probably related with the observed particularities of the combustion processes.

However, it was not obtained any difference in crystallite size and specific area surface values.

Table 1: Average crystallite size and surface specific areas determined by BET for all samples

\begin{tabular}{c|c|c}
\hline ROUTE & $\begin{array}{c}\text { CRYSTALLITE } \\
\text { SIZE } \\
(\mathbf{n m})\end{array}$ & $\begin{array}{c}\text { SURFACE SPECIFIC } \\
\text { AREA } \\
\left(\mathbf{m}^{\mathbf{2}} \mathbf{g}\right)\end{array}$ \\
\hline Ashes ofCoCuMnO-Lis & 10 & 35 \\
\hline CoCuMnO-Lis & 54 & 23 \\
\hline Ashes of CoCuMnO-Asp & 13 & 24 \\
\hline CoCuMnO-Asp & 44 & 13 \\
\hline
\end{tabular}

According to scientific, specialized bibliography, the bands of spinel type oxide in FTIR plots should be found in a region comprised between 400 and $700 \mathrm{~cm}^{-1}$ corresponding to the vibration produced by unions between metal and oxygen. The bands around $500 \mathrm{~cm}^{-1}$ is assigned to a vibration of the metallic atom in the tetrahedral environment of oxygen atom (A-O) and the band around $600 \mathrm{~cm}^{-1}$ correspond to a vibration of B atom in octahedral site (oh) of a spinel structure [5]. In Figs 3 and 4 it can be observed the FTIR spectra for ashes and powders for Lys and Asp respectively.

In the ashes of CoCuMnO-Lys and CoCuMnO-Asp samples, the bands are located at 574 and 575 $\mathrm{cm}^{-1}$ respectively and others at 714 and $752 \mathrm{~cm}^{-1}$. These values are assigned to vibrations between metallic 
and oxygen atoms [ㄷ]. In the spectrum of ofCoCuMnO-Lys sample bands at $567 \mathrm{~cm}^{-1}$ and $673 \mathrm{~cm}^{-1}$ are observed, meanwhile for the spectrum of CoCuMnO-Asp they are located at 571 and $687 \mathrm{~cm}^{-1}$. In pertinent bibliography is reported also that CoCuMnOxpowders have been synthesized by the sol-gel route with characteristic bands between 511 and $599 \mathrm{~cm}^{-1}$ [4] In brief, CoCuMnO-Asp and CoCuMnO-Lys samples show vibrations associated to tetrahedral and octahedral sites in the range of the bands of metallic oxides [5]. These vibrations can be surely associated with the presence of $\mathrm{CoCuMnOx}$ phase in good accord with phase assessment from XRD plotted in Fig. 1 up (Lys) and Fig. 2 (Asp) (see above).

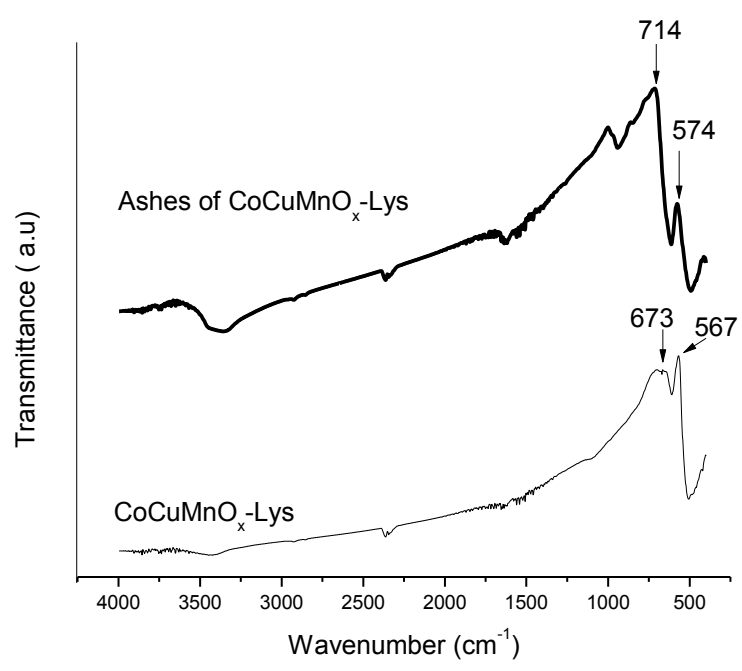

Figure 3: FT-IR of ashes (up) and calcined powders (down) obtained with Lys

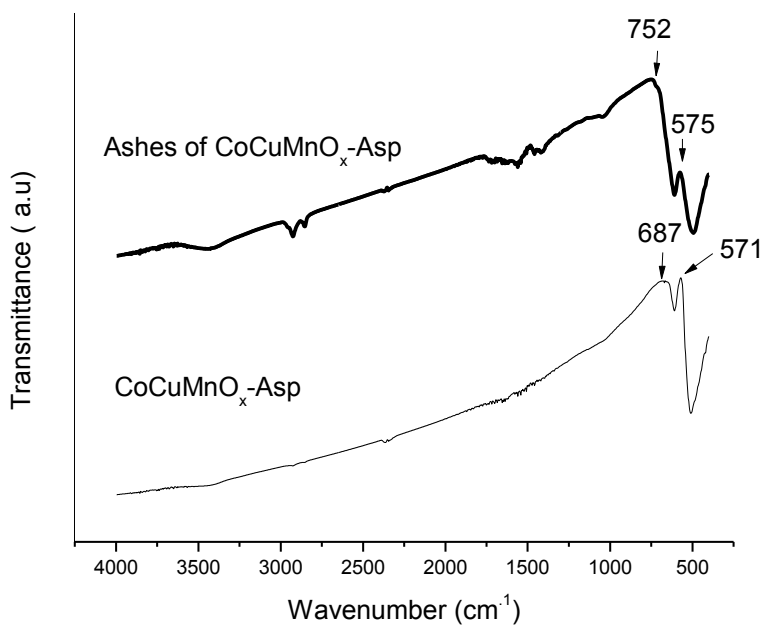

Figure 4: FT-IR of ashes (up) and calcined powders (down) obtained with Asp

By SEM, it was observed that all samples exhibited a high degree of agglomeration, as displayed in Fig. 5 ("a" to "d"). In particular, in CoCuMnO-Lys-ashes (Fig 5(a), it can be observed polyhedral particles. Once calcined this particles growth are more clearly observed as distinct, octahedral particles (Fig 5(b)). Similar polyhedral shapes were observed in $\mathrm{CuCrMnO}_{4}$ powders synthesized by sol-gel routes [1] . With 
regards on the influence of fuels, CoCuMnO-Asp-ashes and CoCuMnO-Asp-calcined powders evidence a lower size of particle and a more open structure than CoCuMnO-Lys-ashes and CoCuMnO-Lys-calcined respectively, probably caused by the different characteristics of the combustion processproduced in the synthesis with Asp fuel where sparks and flame occur. Powders obtained from both syntheses growth after calcination, as is evidently observed, too, in TEM micrographs of Fig. 6.
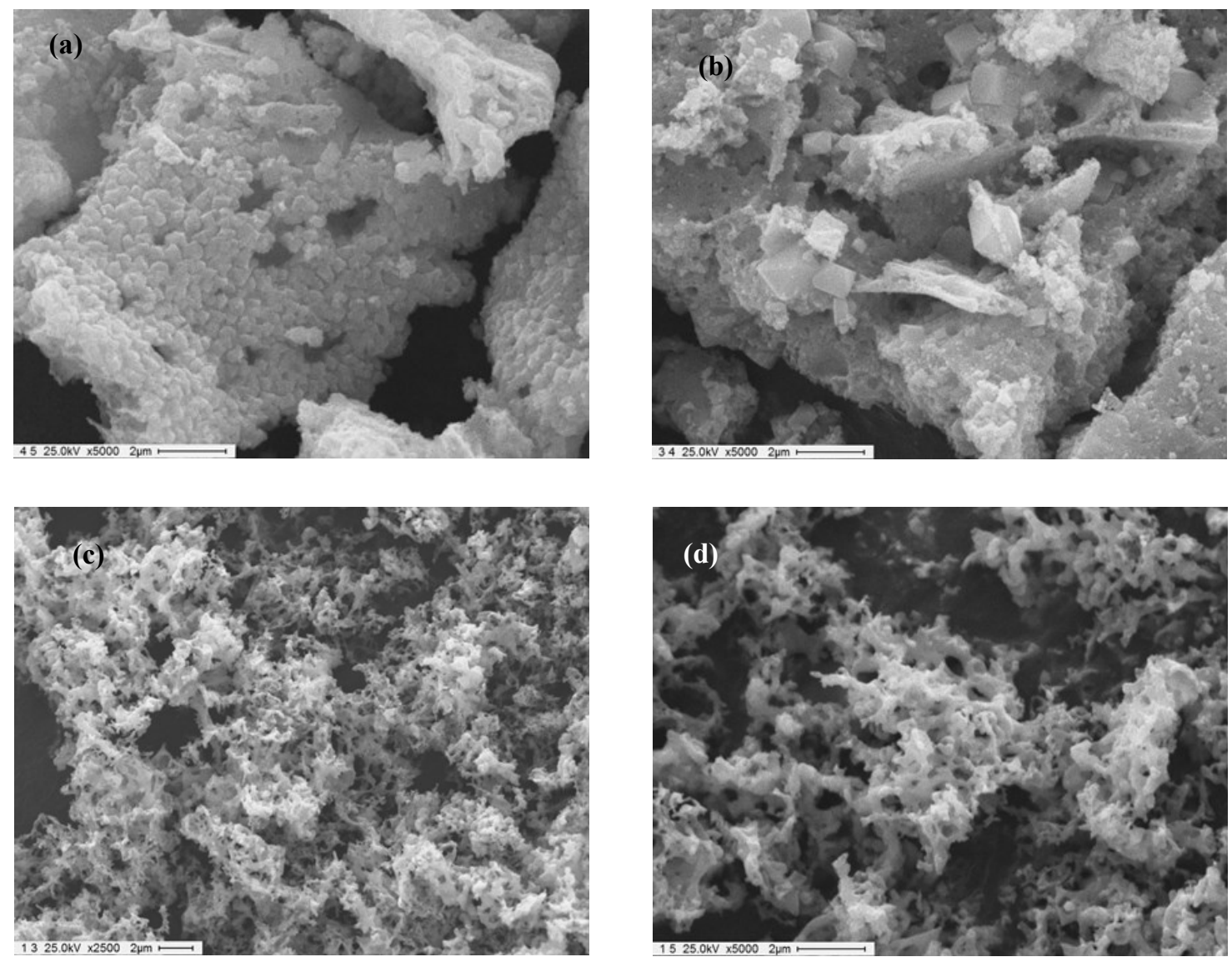

Figure 5: SEM Micrograph of: a) Ashes of CoCuMnO-Lys, (b) CoCuMnO-Lys, (c) Ashes of CoCuMnO-Asp and (d) CoCuMnO-Asp.

As estimated through TEM observations, the particle size ranges from 20 to $100 \mathrm{~nm}$, (scale line $=20$ $\mathrm{nm}$ ), as shown in Fig. 6, where are displayed TEM micrographs of all obtained powders. The polyhedral shape of particles is also evidenced. The average size of particle for CoCuMnO-Lys resulted in $44 \mathrm{~nm}$. In gel combustion synthesis of $\mathrm{CuCr}_{2} \mathrm{O}_{4}$ powders calcined at $500^{\circ} \mathrm{C}$ were reported a similar average particle size of $80 \mathrm{~nm}[\underline{6}$ ]. Additionally these authors studied the influence of calcination temperature on optical properties of pigments [1]. 

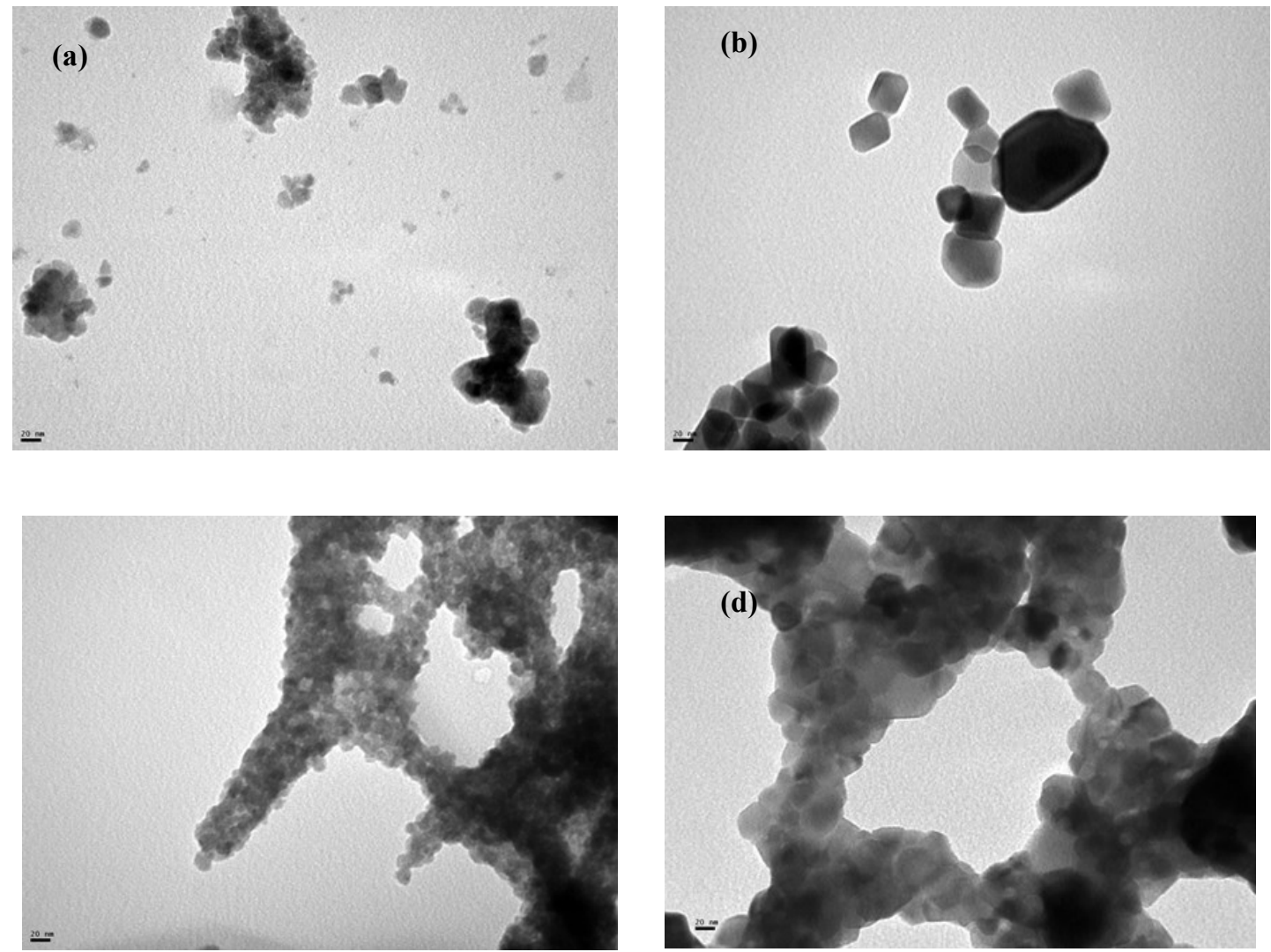

Figure 6: TEM Micrograph of: a) Ashes of CoCuMnO-Lys-ashes, (b) CoCuMnO-Lys-calcined, (c) CoCuMnO-Aspashes and (d) CoCuMnO-Asp.

Ashes obtained by synthesis with aspartic acid were studied by TGA and DTA analysis. The plots are shown in Fig. 7. At 227 and $313{ }^{\circ} \mathrm{C}$ were evident two exothermic peaks. At $227{ }^{\circ} \mathrm{C}$ the peak could be explained as a release of $\mathrm{H}_{2} \mathrm{O}, \mathrm{CO}_{2}$ y $\mathrm{N}_{2}$ gases with a loose of weight of $1.5 \%$ aprox. Similar peaks were observed in xerogels precursors for $\mathrm{CuCrMnO}_{4}$ gels at $227^{\circ} \mathrm{C}$ too [1]. With respect to the $313^{\circ} \mathrm{C}$ peak, it could be associated with a phase transformations from the different spinels detected in ashes $((\mathrm{CoMn}, \mathrm{CuO}$, $\mathrm{MnO}, \mathrm{Co}_{2} \mathrm{MnO}_{4}$ y $\left.\mathrm{CuMn}_{2} \mathrm{O}_{4}\right)$ to $\mathrm{CoCuMnO}_{\mathrm{x}}$ in good accord with the phases evolution observed from DRX diagrams. These transformations involved a loose of weight of $2 \%$ aprox.

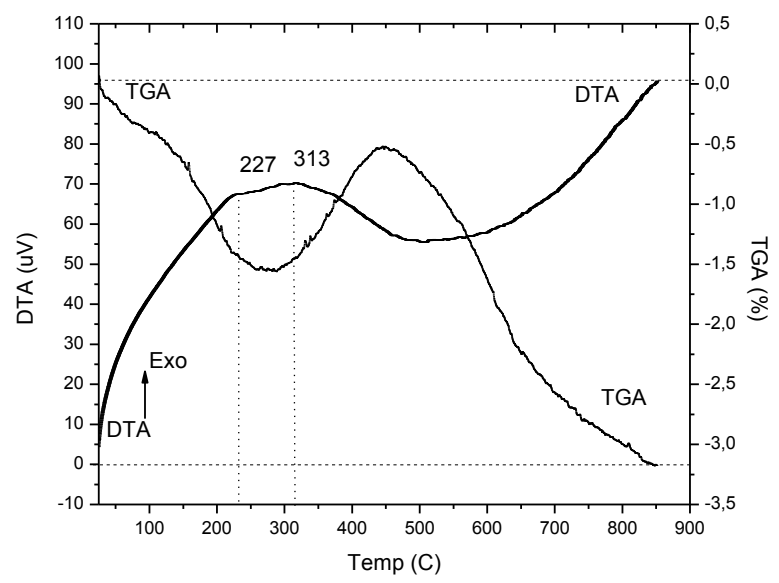

Figure 7: DTA and TGA curves of Asp of CoCuMnO-Asp-ashes between $25^{\circ} \mathrm{C}$ and $850^{\circ} \mathrm{C}$ in air 


\section{CONCLUSIONS}

This work puts forward the synthesis of $\mathrm{Co}, \mathrm{Cu}, \mathrm{Mn}$ mixed oxides- for solar selective paints- by means of original stoichiometric one-step combustion methods starting from $\mathrm{Mn}\left(\mathrm{NO}_{3}\right)_{2}, \mathrm{Co}\left(\mathrm{NO}_{3}\right)_{2} 6 \mathrm{H}_{2} \mathrm{O}$, $\mathrm{Cu}\left(\mathrm{NO}_{3}\right)_{2} 3 \mathrm{H}_{2} \mathrm{O}$ and Aspartic acid (Asp) or Lysine (Lys) as fuels. After combustion, the resulting ashes were calcined at $500{ }^{\circ} \mathrm{C}$. Both oxides present the CoCoMnOx crystalline phase, wherever for Lys powders appear segregated phases. The average crystallite size calculated with Scherrer equation was $44 \mathrm{~nm}$ for Lys powders and $54 \mathrm{~nm}$ for Asp, meanwhile, the specific surface areas were 23 and $13 \mathrm{~m}^{2} / \mathrm{g}$ respectively. Throughout FTIR, it appeared vibrations associated with spinel metallic oxides for both calcined powders (Asp and Lys).

Additionally, it was observed, by means of TEM, polyhedral particles with an average size of 20 to $100 \mathrm{~nm}$. In particular, an average size of $44 \mathrm{~nm}$ in $\mathrm{CoCuMnO}_{\mathrm{x}}$-Lys was determined. According to the different fuels used (Asp and Lys), an evident variations in the obtained phases and surface morphology were observed. Probably these differences are related with the particular characteristics observed in each combustion processes. However, it was not obtained any significant difference in crystallite size and specific area surface values. It is of considerable importance the study of further syntheses processes to verify this trend.

\section{ACKNOWLEDGMENTS}

Authors thank founds received from NTU, Regional Faculty Mendoza,through the PID INN1342 Project.

\section{BIBLIOGRAPHY}

[1] GENG, Q., ZHAO, X., GAO, X., et al., "Optimization design of $\mathrm{CuCr}_{\mathrm{X}} \mathrm{Mn}_{2-\mathrm{x}} \mathrm{O}_{4}$-based paint coatings used for solar selective applications", Solar Energy Materials \& Solar Cells, v.105, pp. 293-301, Jul.2012.

[2] GENG, Q., ZHAO, X., GAO, X., et al., "Sol-Gel Combustion-Derived $\mathrm{CoCuMnO}_{\mathrm{x}}$ Spinels as Pigment for Spectrally Selective Paints", Journal of the American Ceramic Society, v. 94, n.3, pp. 827-832, 2011.

[3] VINCE, J., ŠURCA VUK, A., OPARA KRAŠOVEC, U., et al., "Solar absorber coatings based on $\mathrm{CoCuMnO}_{\mathrm{x}}$ spinels prepared via the sol-gel process: structural and optical properties", Solar Energy Materials \& Solar Cells, v. 79, pp. 313-330, 2003.

[4] KALUŽA, L., OREL, B., DRAŽIČ, G., et al., "Sol-gel derived $\mathrm{CuCoMnO}_{\mathrm{x}}$ spinel coatings for solar absorbers: Structural and optical properties"., Solar Energy Materials \& Solar Cells, v. 70, pp. 187-201, 2001.

[5] HOSSEINI, S.A., ALVAREZ-GALVAN, M.C., FIERRO, J.L.G., et al., " $\mathrm{MCr}_{2} \mathrm{O}_{4}(\mathrm{M}=\mathrm{Co}, \mathrm{Cu}$, and $\mathrm{Zn})$ nanospinels for 2-propanol combustion: Correlation of structural properties with catalytic performance and stability", Ceramics International, v. 39, pp. 9253, 2013.

[6] GENG, Q., ZHAO, X., GAO, X., et al., "Low-temperature combustion sinthesys of $\mathrm{CuCr}_{2} \mathrm{O}_{4}$ spinel powder for spectrally selective paints", Journal of Sol-Gel Science and Technology, v. 61, I 1, pp. 281-288, 2012.

[7] TONIOLO J, C., LIMA, M.D., TAKIMI, A. S., et al., "Synthesis of alumina powders by the glycinenitrate combustion process", Materials Research Bulletin, v. 40, pp. 561-571, 2012.

[8] RAO K. V., SUNANDANA, C. " $\mathrm{Co}_{3} \mathrm{O}_{4}$ nanoparticles by chemical combustion: Effect of fuel to oxidizer ratio on structure, microstructure and EPR", Solid State Communications, v. 148, pp.32-37, 2008.

[9] TONIOLO, J., TAKIMI, A., BERGMANN, C. "Nanostructured cobalt oxides $\left(\mathrm{Co}_{3} \mathrm{O}_{4}\right.$ and $\left.\mathrm{CoO}\right)$ and metallic Co powders synthesized by the solution combustion method". Materials Research Bulletin, v 45, pp 672-676, 2010.

[10] NOROUZBEIGI, R., EDRISSI, M. "Modification and optimization of nano-crystalline $\mathrm{Al}_{2} \mathrm{O}_{3}$ combustion synthesis using Taguchi L16 array", Materials Research Bulletin, v. 46, pp 1615-1624, 2011. 